\title{
REPRODUKSI WACANA METABO LAW DALAM PEMBENTUKAN STEREOTYPE FAT CHARACTER PADA ANIME JEPANG
}

\author{
Santi Andayani*, Ni Made Savitri Paramita \\ Program Studi Sastra Jepang Universitas Brawijaya \\ santi_anda@yahoo.co.id, madesavitriparamita@gmail.com
}

\begin{abstract}
Abstrak
Kementrian Kesehatan, Buruh, dan Kesejahteraan Jepang pada tahun 2008 mengeluarkan peraturan yang disebut sebagai Metabo Law, yaitu standar mengenai pemeriksaan dan bimbingan kesehatan yang bertujuan untuk menurunkan angka obesitas sebagai salah satu penyebab terjadinya metabolic syndrome. Dengan peraturan ini, maka tubuh yang merupakan wilayah privat telah diintervensi oleh pemerintah sehingga menjadi wilayah publik. Dengan menggunakan perspektif Foucault, maka penelitian ini bertujuan untuk mendeskripsikan bagaimana Metabo Law beroperasi dan bagaimana reproduksi wacana tersebut berpengaruh dalam membentuk stereotypefat character pada anime Jepang. Penelitian ini mengambil sampel data 15 fat character dari 14 judul anime yang tayang pada tahun 2008-2016. Untuk melengkapi data, dilakukan wawancara terhadap 5 orang Jepang untuk megetahui sejauh mana Metabo Law telah dilakukan. Hasil penelitian menunjukkan bahwa dengan proses normalisasi berupa pemeriksaan kesehatan tahunan dan reproduksi wacana Metabo Law, pemerintah Jepang telah berhasil mengubah pola pikir dan cara berprilaku penduduk Jepang untuk hidup lebih sehat dengan bertubuh langsing. Kemudian, stereotype fat character yang muncul dari reproduksi wacana Metabo Law adalah rakus, ceroboh, penakut, pemalu/ tidak percaya diri, dan seorang otaku.
\end{abstract}

Kata kunci: Metabo law; stereotype; fat character; wacana; proses normalisasi

\begin{abstract}
(Title: The Reproduction Of Metabo Law Discourse In Constructing Fat Characters Stereotype In Japanese Animes) Japanese government through Ministry of Health, Labor and Welfare (MHLW) in 2008 issued the Metabo Law regulation, which is the standard of medical and health guidance that is done specifically with the purpose to decrease the number of obesity which cause the metabolic syndrome. This regulation put the body of each individual to be open to the public. Using Foucault's perception, this study look how Metabo Law works and how the reproduction of Metabo Law discourses constructing stereotype of fat character in Japanese anime. This study took data from 14 fat character in 13 anime, airing in 2008 's until 2015 's. To complete the data, interview were conducted on 5 Japanese about their understanding about Metabo Law. This study shows that with the normalization process using yearly general checkup and the reproduction of Metabo Law discourses, Japanese government successfully change the Japanese mindset and their behavior in maintained a healthy life style and to stay slim. The stereotype of the fat character that emerge as the product of reproduction of Metabo Law discourses is greedy, careless, cowardly, shy/ have low self-confident, and an otaku.
\end{abstract}


Keywords: Metabo Law; stereotype; fat character; discourse; normalization process

\section{PENDAHULUAN}

Pemerintah Jepang melalui Kementrian Kesehatan, Buruh, dan Kesejahteraan (MHLW) mengeluarkan peraturan yang disebut sebagai Metabo Law, yaitu standar mengenai pemeriksaan kesehatan dan bimbingan kesehatan yang dilakukan secara khusus. Peraturan ini dikeluarkan tahun 2008 sebagai usaha pemerintah Jepang dalam melawan obesitas dan metabolic syndrome. Hal ini dilakukan menyikapi hasil penelitian OECD (the Organization for Economic Co-operation and Development) yang menyatakan bahwa obesitas telah menjadi isu yang meluas dan cenderung akan mengalami peningkatan di tiap negara. Melalui Metabo Law, MHLW memberikan mandat pada pemerintah daerah dan perusahaan-perusahaan untuk melakukan medical check up yang dilakukan setiap tahun. Sasaran peserta medical check up ini adalah laki-laki dan perempuan usia 40-74 tahun (Onishi via Oda, 2010). Medical check up ini meliputi pemeriksaan kesehatan standar dan penghitungan lingkar pinggang tiap individu.Ukuran lingkar pinggang maksimum untuk laki-laki adalah 33.5 inchi $(85 \mathrm{~cm})$ dan $35.4(90 \mathrm{~cm})$ untuk perempuan. Laki-laki maupun perempuan yang melebihi standar tersebut akan diikutkan bimbingan konseling, dimonitor melalui telepon dan e-mail, serta diberi motivasi dukungan sesuai kondisi mereka (Oda, 2010).

Tubuh yang merupakan wilayah privat telah diintervensi oleh pemerintah dengan adanya Metabo Law ini.Foucault menggolongkan hal ini dalam bio power, di mana kekuasaan mengatur kaidah-kaidah yang melandasi produksi wacana, salah satunya melalui aturan-aturan dalam ilmu kedokteran. Foucault menyatakan bahwa kekuasaan beroperasi di mana terdapat susunan, aturan-aturan, sistem regulasi atau di mana saja manusia mempunyai hubungan tertentu satu sama lain. Kekuasaan bekerja secara tidak kasat mata dan membuat kekuasaan seolah-olah menjadi tidak disadari sehingga seseorang dengan rela melaksanakan apa yang dikehendaki oleh kekuasaan tanpa dia sadari (Mudhoffir, 2013). Oleh karena itu, kuasa tidak selalu bekerja melalui penindasan dan represi, tetapi terutama melalui normalisasi dan regulasi. Publik tidak dikontrol lewat kekuasaan yang sifatnya fisik, tetapi dikontrol, diatur, dan didisiplinkan lewat wacana dan mekanisme berupa prosedur, aturan, tata cara, dan sebagainya.

Salah satu bidang normalisasi dan pendisiplinan adalah tubuh, di mana tubuh dianggap sebagai mesin yang harus dioptimalkan kapabilitasnya, tubuh dibuat berguna dan patuh.Tubuh yang merupakan wilayah privat telah terbuka menjadi wilayah publik.Pemerintah Jepang melalui wacana Metabo Law mendikte masyarakat Jepang untuk bertindak dan berperilaku sesuai dengan keinginan pemerintah untuk berperan dalam masyarakat.

Hal ini dilakukan dengan terus melakukan poduksi dan reproduksi wacana tentang obesitas dan metabolic syndromedalam masyarakat, tidak hanya melalui institusi-institusi namun peran media dan produk-produk budaya turut mendukung terciptanya kesadaran masyarakat untuk lebih memperhatikan kesehatan dan penampilannya.Penyebaran kesadaran ini tidak lepas dari adanya body image dan body dissatisfaction.Berbagai usaha dilakukan masyarakat untuk menjaga body image dan menghindari body dissatisfaction, seperti melakukan diet ketat dan mengkonsumsi berbagai produk 
pelangsing.Masyarakat yang mengidealkan tubuh langsing dan adanya pengetahauan tentang bahayanya obesitas ini mengarahkannya pada pandangan bahwa obesitas sebagai hal yang negatif, sehingga saat Metabo Law diimplementasikan tidak banyak pertentangan dan semua mematuhi peraturan ini.

Penelitian mengenai Metabo Law pernah dilakukan oleh Barron T. Oda dengan judul An Alternative Perspective to Battling The Bulge: The Social and Legal Fallout of Japan's Anti-Obesity Legislation. Dalam penelitiannya dibicarakan tentang Metabo Law yang dicanangkan pemerintah Jepang dalam rangka menurunkan tingkat obesitas pada penduduk Jepang usia pertengahan dan usaha untuk mengurangi resiko penyakit kronis seperti komplikasi jantung, stroke, diabetes dan darah tinggi. Oda menyebutkan krisis kesehatan yang dihadapi Jepang bukanlah tingginya tingkat obesitas, melainkan krisis perawatan kesehatan yang besar dan sistem pembayaran pelayanan kesehatan di Jepang dikarenakan adanya populasi menua.Jadi, penelitian yang dilakukan oleh Oda lebih menyoroti mengenai pelaksanaan Metabo Law dan pengaruhnya terhadap masalah krisis perawatan kesehatan di Jepang, sedangkan penelitian ini mengangkat Metabo Law dalam kaitannya dengan wacana kekuasaan pemerintah Jepang untuk mengontrol dan mengatur tubuh masyarakatnya melalui media budaya populer, yaitu anime.

Wacana Metabo Law melalui anime yang berupa gambar kartun menjadi alat efektif bagi reproduksi wacana karena dibungkus dalam kemasan menghibur, di mana kontrol negara tidak akan terlihat dengan jelas sebagai suatu bentuk pengawasan. Bentuk reproduksi wacana dalam anime mengenai Metabo Lawakan dilihat melalui character tokoh-tokoh yang ditampilkannya.

Berdasarkan latar belakang di atas, maka penelitian ini akan meneliti bagaimana kekuasaan negara Jepang, yaitu melalui Metabo Law beroperasi hingga reproduksi wacananya, terutama dalam pembentukan stereotype fat character pada anime Jepang.

Oleh karena itu, penelitian ini bertujuan untuk mendeskripsikan peranan negara melalui regulasi Metabo Law dan reproduksi wacananya dalam pembentukan stereotype fat character pada anime Jepang. Penelitian ini diharapkan akan menambah wawasan tentang adanya hidden message negara melalui regulasi-regulasinya untuk mengatur tubuh masyarakatnya dan adanya proses produksi dan reproduksi wacana yang mampu mempengaruhi pembentukan stereotype di masyarakat

\section{METODE PENELITIAN}

Penelitian ini adalah penelitian deskriptif. Teknik pengumpulan data dilakukan dengan studi pustaka. Sumber data primer adalah kajian tentang Metabo Law dan anime Jepang yang tayang antara rentang waktu tahun 2008-2015. Alasan pemilihan rentang waktu ini disesuaikan dengan keluarnya Metabo Law di Jepang yaitu pada tahun 2008. Dari hasil sampling ditetapkan 15 fat character dari 13 judul anime, yaitu Baka Oji dalam anime Gintama (2008), Majin Buu dalam anime Dragonball (2008), Gluttony dalam anime Full Metal Alchemist (2009), Tom dalam anime One Piece (2009), Kouta Hirano dalam anime High School of the Dead (2010), Chieko dalam anime Kuragehime (Princess Jellyfish) (2010), Itaru Hasida dalam anime Stein;s Gate (2011), Milluki Zoldyck dalam anime Hunter $x$ Hunter (2011), Hanako Ohtani dalam anime 
Izumi, Volume 7 No 1, 2018

e-ISSN: 2502-3535, p-ISSN: 2338-249X

Tersedia online di http://ejournal.undip.ac.id/index.php/izumi

Persona 4 the Animation (2011), Harayuki Arita dalam anime Accel World (2012), Tamako Inada dalam anime Gin no Saji (2013), Choji Akimichi dalam anime Naruto Shippuden (2015), Yuriko Gouda dan Takeo Gouda dalam anime Ore Monogatari (2015).

Untuk data sekunder, selain dengan memanfaatkan buku, artikel, dan jurnal yang mendukung penelitian, juga dilakukan melalui wawancara sebagai instrumen penelitian, yaitu melakukan kegiatan tanya jawab dengan menggunakan pedoman wawancara pada 5 informan untuk mengetahui tanggapan mereka terhadap wacana Metabo Law tersebut. Pemilihan 5 informan dilakukan dengan metode purposeful sampling, di mana informan yang dipilih merupakan warga Jepang yang diasumsikan memiliki pengetahuan mengenai Metabo Law.

Teknik analisis data dilakukan dengan cara mencari bentuk implementasi Metabo Law dan menganalisis bagaimana kemudian regulasi tersebut bekerja dan bagaimana masyarakat Jepang kemudian melaksankannya. Selanjutnya adalah menganalisis bentuk reproduksi wacana tersebut dalam anime Jepang.

\section{HASIL DAN PEMBAHASAN}

Berikut akan dijelaskan bagaimana Metabo Law sebagai sebuah regulasi bekerja sehingga apa yang diinginkan oleh pemerintah Jepang terhadap penduduknya melalui regulasi tersebut berhasil dilaksanakan dan bagaimana reproduksi dari wacana tersebut berpengaruh pada industri anime di Jepang.

\subsection{Peran Regulasi Metabo Law dalam Pembentukan Stereotype Fat Character Pada Anime Jepang}

Jepang saat ini tengah menghadapi apa yang dikenal sebagai koureika shakai, kondisi negara di mana warga usia lanjut terus meningkat populasinya, yaitu banyaknya penduduk berusia 65 tahun ke atas (Sally, $2016: 2$ ). Semakin banyaknya lansia menyebabkan beban negara atas pengeluaran di bidang kesehatan pun turut bertambah besar sehingga keberadaan asuransi sebagai salah satu alat dari program kesehatan pemerintah diintervensi dan dikontrol seperti dalam hal pengaturan pembiayaan. Dengan demikian, pekerjaan dokter tidak hanya menyembuhkan pasien saja, namun juga sebagai alat negara untuk menjaga kesehatan masyarakat, yang pada akhirnya akan mendukung kepentingan negara dalam menurunkan anggaran untuk pengobatan. Dari kondisi ini bisa dilihat bagaimana politik medis yang terbentuk akan bekerja.

Kementerian Kesehatan, Kesejahteraan, dan Tenaga Kerja kemudian mengeluarkan kebijakan yang berdasar pada UU no 7 tahun 2008 tentang Hukum Mengenai Perlindungan Kesehatan Lansia yang diantaranya berisi tentang otorisasi untuk melakukan pemeriksaan kesehatan tahunan secara wajib kepada semua warga berusia lebih dari 40 tahun, maka dikeluarkanlah regulasi lain yang dikenal sebagai Metabo Law, yaitu seperangkat pedoman tentang Standar Pelaksanaan Pemeriksaan Kesehatan Khusus dan Bimbingan Kesehatan untuk Masyarakat Khusus yang dikeluarkan pada 1 April 2008. Melalui Metabo Law, sekitar 56 juta jiwa penduduk berusia 40-74 tahun harus menyerahkan pemeriksaan kesehatan tahunan di mana salah satu itemnya adalah pengukuran lingkar pinggang. Untuk pria lingkar pinggang maksimal adalah $85 \mathrm{~cm}$ dan wanita maksimal $90 \mathrm{~cm}$. Hal yang menarik adalah kenapa pada usia ini? Dan kenapa ditambah dengan lingkar pinggang? Sebagaimana nama peraturannya, yaitu Metabo Law, istilah metabo merupakan sebutan bagi metabolic syndrome, suatu sindrom yang merupakan kombinasi dari sejumlah kondisi, yaitu tekanan darah tinggi (hipertensi), kadar gula darah tinggi, kadar kolesterol tinggi, dan obesitas, yang dialami secara bersamaan. 
Kondisi-kondisi yang terdapat dalam sindrom metabolik akan mengarah pada resiko terkena penyakit serius seperti serangan jantung, stroke, dan diabetes. Sebagai gambaran mengenai salah satu datanya, yaitu pada tahun 1997 jumlah penderita diabetes sekitar 6.9 juta dan meningkat menjadi 8.9 juta pada tahun 2008. Dari peningkatan jumlah penderita ini dipastikan pengeluaran anggaran kesehatan akan bertambah pula. Dengan kondisi ini, maka banyak ahli kesehatan yang kemudian mendukung dikeluarkannya regulasi Metabo Law (Nakamura, 2009).

Menurut hasil penelitian OECD (the Organization for Economic Co-operation and Development) menyatakan bahwa obesitas telah menjadi isu yang meluas dan cenderung akan mengalami peningkatan di tiap negara. Jepang menjadi salah satu negara yang berhasil mengurangi angka obesitas penduduknya dan tergolong negara paling rendah tingkat obesitasnya. Untuk perbandingan di negara maju, seperti Amerika memiliki tingkat obesitas 33,9\% sedang Jepang hanya 3,1\%. Obesitas ini mulai banyak menyerang pada usia sekitar 40 tahun ke atas. Oleh sebab itu, sasaran pemeriksaan pada Metabo Law diperuntukkan bagi semua pria-wanita pada usia 40-74 tahun. Bahkan, beberapa perusahaan di Jepang telah mewajibkan karyawannya yang berusia 30 tahun ke atas untuk mengikutinya. Perusahaan Matsushita misalnya, pengukuran lingkar pinggang ini tidak hanya berlaku untuk karyawannya saja, namun juga keluarga dan para pensiunanya pun juga ikut pengecekan metabo (Norimitsu, 2008).

Meskipun Jepang memiliki tingkat obesitas rendah, namun karena ada kecenderungan sindrom metabolik meningkat, maka Metabo Law tetap dijalankan. Alasan pertambahan sindrom metabolik ini sebenarnya lebih kepada perubahan gaya hidup. Pasca Perang Dunia II, peningkatan kemakmuran ekonomi di Jepang berpengaruh pada transisi nutrisi yang dikombinasi pula dengan penurunan ketergantungan pada tenaga kerja manual (berubah ke mesin/ robot) sehingga menghasilkan gaya hidup yang tidak sehat dan menyebabkan prevalensi obesitas dan penyakit terkait lainnya menjadi meningkat. Selain itu, pendapatan yang lebih besar di Jepang mengakibatkan akses terhadap makanan pun menjadi lebih bervariasi (Richard dalam Nandini, 2011).

Menurut dunia kedokteran, obesitas merupakan komponen utama kejadian sindrom metabolik, maka salah satu cara untuk bisa mengenali adanya sindrom metabolik adalah dengan pengukuran lingkar pinggang. Maka, ketika lingkar pinggang melebihi dari ukuran standar yang telah ditetapkan, dokter akan mempertimbangkannya dengan hasil tes pemeriksaan lain seperti tes analisis lemak dan tekanan. Dari situ dokter bisa memberi gambaran pada pasien tentang tingkat keparahan metabo atau kerentanannya terhadap penyakit kronis lainnya. Pasien yang berada pada kategori paling rentan diwajibkan untuk menghadiri sesi konseling yang dilakukan selam 3 bulan melalui telepon atau e-mail. Untuk kategori yang paling rendah tingkat kerentanannya diberikan motivasi untuk menurunkan berat badan.

Regulasi-regulasi ini merupakan salah satu strategi kekuasaan pemerintah Jepang dalam menurunkan angka obesitas penduduknya di mana hal ini saling terkait seperti dengan masalah dalam dunia kesehatan, politik, ekonomi, sosial, dan budaya. Sepeti yang dikatakan oleh Foucault bahwa strategi kekuasaan merupakan kehendak untuk mengetahui, maka melalui wacana Metabo Law, kehendak untuk mengetahui kondisi penduduk Jepang terumus dalam pengetahuan medis, dan pandangan serta cara pengobatan seorang dokter tidaklah hanya dipengaruhi oleh satu kondisi saja, tetapi juga sangat dipengaruhi oleh berbagai kondisi lainnya seperti pengetahuan, institusional, pedagogis, keamanan, dan sebagainya. Negara memberikan kekuasaan 
kepada dokter untuk menyelenggarakan praktik kesehatan dan dokter dengan pengetahuan medis yang dimilikinya mampu menentukan tingkat keparahan penyakit pasien. Hal ini akan saling mengisi dengan keinginan pemerintah untuk mengurangi anggaran kesehatan dengan membuat penduduknya sehat.

Foucault menjelaskan bahwa fenomena disiplin tubuh selalu dikontrol oleh dua instrumen disiplin yang diterapkan dari disiplin militer; melalui observasi hierarkis atau kemampuan aparatus untuk mengawasi semua yang berada di bawahnya dalam satu kriteria, dan menormalkan penilaian moral dan menghukum para pelanggar moral.Kedua instrumen ini terkombinasi dalam wujud tes/ ujian.Demikianpun pemerintah Jepang, dengan memberikan kekuasaan pada dokter-dokter di rumah sakit, pemerintah berhasil mendikte warganya yang berusia di atas 40 tahun untuk wajib mengikuti tes kesehatan setiap tahunnya.Tes ini merupakan pusat dari prosedur kesehatan yang mengkonstitusi tubuh individu sebagai efek dan objek dari kekuasaan, sebagaimana test itu sendiri sebagai efek dan objek dari pengetahuan. Tes ini mengenalkan warga Jepang pada pendokumentasian, yaitu berupa lembar hasil pemeriksaan kesehatan. Lembar ini berisi rekaman pemeriksaan kesehatan yang pernah dilakukan pasien dan dari lembar itu bisa selalu dikontrol kondisi pasien. Dalam kaitanya dengan Metabo Law, maka lembar hasil pemeriksaan tersebut akan bisa menjadi pengontrol pasien untuk selalu menjaga kondisinya agar berat tubuhnya normal/ tidak melebihi standard pengukuran test. Lembar hasil test kesehatan ini bisa dibilang sebagai panopticon dalam istilah Foucault, yaitu bentuk fisik dari kedua instrumen disiplin yang bertugas sebagai pengawas. Panopticon ini juga berfungsi sebagai laboratorium, tempat untuk melakukan eksperimen terhadap penduduk Jepang, mengumpulkan informasi mengenai kesehatan mereka serta menganalisis secara menyeluruh apa yang bisa dicapai dari prilaku mereka. Meskipun tidak diawasi secara fisik, namun kehadiran pengawas seolah hadir dari lembar kertas tersebut karena melaluinya jejak rekam medis tiap individu selalu bisa dipantau. Efek dari lembar hasil test kesehatan selanjutnya adalah munculnya kesadaran individu untuk selalu menjaga tubuhnya supaya timbangan berat badannya tidak bertambah atau lingkar perutnya tidak semakin besar. Kehadiran lembar hasil tes kesehatan menjadi suatu mekanisme kekuasaan dan disiplin yang luar biasa karena mampu memberikan power of mind, yaitu instrumen untuk menciptakan individu sesuai yang diharapkan.Kesadaran yang muncul ini menjamin berlangsungnya fungsi kekuasaan secara otomatis dan meskipun pengawasan ini dilakukan secara tidak kontinyu yaitu setahun sekali, namun efek dari pemeriksaan kesehatan yang dirasakan berlangsung secara kontinyu.

Kemudian, efek lain dari Metabo Law ini adalah setiap orang Jepang yang telah mencapai usia sasaran dengan kesadarannya akan mengikuti tes tersebut, meskipun orang tersebut tengah berada di luar negeri. Hal ini seperti yang diungkapkan oleh 2 interviewee yang kebetulan adalah suami istri berusia 70 tahun ke atas yang saat ini tinggal sementara di Indonesia. Mereka mengatakan akan melakukan tes kesehatan ketika pulang ke Jepang dan hal ini dilakukannya secara rutin dan dianggap hal yang normal. Interviewee yang lain menyatakan jika sudah waktu usianya tiba untuk melakukan pemeriksaan, maka mereka pun juga akan mematuhi aturan tersebut. Meskipun ada yang tidak paham mengenai peraturan metabo law, namun hampir semua para interviewee menyetujui peraturan tersebut.Sebagian besar beranggapan bahwa peraturan tersebut dibuat untuk menjaga kesehatan tubuh penduduk Jepang, jadi tidak ada masalah tentangnya.Ada yang berpendapat bahwa peraturan itu menjadi semacam standar dan juga pengingat agar selalu menjaga tubuhnya karena metabo bisa 
berkaitan dengan penyakit lainnya. Bahkan, seorang interviewee berpendapat akan lebih baik jika target usia peserta tes bisa diturunkan lagi usianya sehingga pencegahan bisa dilakukan lebih dini.

Dari pendapat di atas bisa dikatakan bahwa proses normalisasi untuk membuat tubuh yang langsing sebagai tubuh yang normal dan kegiatan pemeriksaan kesehatan tahunan sebagai hal yang normal bagi semua warga Jepang telah berhasil. Bahkan, beberapa interviewee menyatakan akan melakukan persiapan terlebih dahulu seperti diet, memilih makanan yang sehat, atau rutin berolahraga seminggu sebelum melakukan pemeriksaan kesehatan.

Hasil dari proses normalisasi tersebut juga terlihat dari warga Jepang yang tidak menentang peraturan tersebut. Beberapa interviewee menyatakan bahwa alasan orang Jepang mejadi langsing bisa dibilang berkat adanya peraturan ini karena banyak yang kemudian berhati-hati menjaga kesehatannya supaya tidak terkena sindrom metabolik. Selain itu, karena peraturan ini diterapakan di perusahaan tempat mereka bekerja maka setiap orang akan berusaha untuk memenuhi standar pemeriksaan dan sekaligus usaha untuk meningkatkan produktivitas mereka karena perusahan pun menginginkan pekerjanya sehat, cekatan, tidak sering absen karena sakit, juga mengurangi biaya perawatan kesehatan karyawan.

Pada akhirnya, karyawan akan selalu mengikuti pemeriksaan ini bukan karena ancaman dari atasan seperti akan dikeluarkan dari pekerjaannya jika sering absen kerja karena sakit, tidak bisa memenui tugasnya secara cekatan, dll, tetapi lebih pada alasan karena adanya regulasi-regulasi yang menormalkan tindakannya dan adanya semacam struktur diskursif yang mengatakan akan ada penghargaan bagi karyawan yang produktif dan berprestasi dalam bekerja. Proses normalisasi melalui tes kesehatan ini bisa dikatakan telah berhasil mengubah pola pikir dan perilaku masyarakat Jepang untuk lebih peduli terhadap kesehatannya.

Kemudian, dari proses normalisasi yang terjadi, muncullah proses lain yang berkembang, yakni proses inklusi dan eksklusi, yakni adanya peminggiran pada individu atau kelompok yang dianggap berada di luar kenormalan. Bagi Foucault, kekuasaan akan selalu teraktualisasi melalui pengetahuan, dan pengetahuan selalu punya efek kuasa. Kekuasaan selalu ditopang dengan suatu ekonomi wacana kebenaran.Kebenaran yang dimaksud disini adalah kebenaran yang diproduksi, karena setiap kekuasaan memproduksi dan menghasilkan kebenaran sendiri melalui mana semua orang digiring untuk mengikuti kebenaran yang telah diciptakan itu.Yang terjadi kemudian adalah persepsi orang tentang suatu objek dibatasi oleh praktik diskursif, yaitu dibatasi oleh pandangan yang mendefinisikan sesuatu itu benar atau salah.Ketika wacana Metabo Law tercipta, maka pandangan orang Jepang diarahkan pada jalan pikiran tertentu dan memahami itu sebagai yang benar, yaitu gemuk adalah salah dan langsing adalah benar.

Meskipun wacana gemuk/ langsing tidak hanya ada ketika wacana Metabo Law muncul, namun wacana ini lebih memperkuat dan menormalkan jalan pikiran masyarakat tentang pandangannya terhadap tubuh gemuk-langsing, sehingga muncullah pandangan atau pencintraan seperti langsing identik sehat dan gemuk sebaliknya; gemuk sama dengan jelek dan langsing sama dengan cantik/ tampan; langsing adalah normal dan gemuk adalah abnormal. Dari pencintraan tersebut orang kemudian terbagi dalam golongangolongan. Di sinilah terjadi proses inklusi dan eksklusi di mana orang yang dianggap tidak normal akan dipinggirkan.

Regulasi Metabo Law bisa dikatakan telah turut menyumbang dalam pengonstruksian tubuh sehat penduduk Jepang. Hal ini karena regulasi Metabo Law 
telah menjadi peraturan yang wajib diikuti oleh mereka yang telah mencapai sasaran usia pemeriksaan yaitu 40 tahun ke atas, sehingga penyebaran pengetahuan atau informasi terkait metabo banyak dilakukan oleh pemerintah dan direproduksi wacananya dalam berbagai bentuk. Dari tayangan program kesehatan di televisi, penyebarannya di internet, iklan, poster, dll. menjadikan wacana ini seharusnya dikenal lebih luas. Banyak kemudian pandangan yang berkembang di masyarakat yang melihat bahwa orang dengan tubuh yang kegemukan identik dengan tidak sehat karena kegemukan bisa mengarah pada suatu penyakit. Orang kemudian berlombalomba untuk menguruskan badannya, baik dengan tujuan untuk hidup lebih sehat ataupun hanya sekedar body image ingin tampil cantik seperti yang dikatakan oleh beberapainterviewee, yaituketika umur sudah lebih dar 30 tahun orang ingin langsing kebanyakan demi alasan kesehatan, dan yang masih muda atau kurang dari 30 tahun kebanyakan hanya untuk penampilan.

Kecenderungan untuk tampil langsing lebih banyak terjadi pada wanita, terutama wanita muda. Apalagi dengan maraknya grup-grup idol di Jepang. Imej langsing juga terjadi hingga istilah 'fukkinjo' populer di Jepang, yaitu sebutan bagi wanita yang berhasil memiliki perut berotot di mana tidak terlihat timbunan lemak sama sekali di perutnya. Pendapat seperti ini senada dengan yang diungkapkan oleh salah seorang dari interviewee.

Kondisi ini, meskipun terlihat tidak secara langsung berkaitan dengan metabo, namun keinginan untuk bertubuh langsing penduduk Jepang inisejalan dan berkaitan dengan tujuan pemerintah untuk mengurangi obesitas dan adanya Metabo Law akan lebih memperkuat penyebaran wacananya. Program kesehatan pemerintah salah satunya tersebar lewat media hiburan seperti anime. Kampanye tersebut bisa dilakukan seperti melalui plot, setting, atau dengan menciptakan citra cantik, tampan, sehat, ramping, dan lincah pada karakter tokoh-tokohnya sehingga terbentuk stereotype dimana hal ini mendorong pengkonstruksian tubuh yang diinginkan oleh pemerintah, yaitu tubuh yang sehat dan langsing.

\subsection{Stereotype Fat Character Dalam Anime Jepang Sebagai Bentuk Reproduksi Wacana Metabo Law}

Pada bab sebelumnya telah dijelaskan bahwa reproduksi wacana Metabo Law ikut menyebar ke industri hiburan anime yang salah satunya dengan terciptanya stereotype karakter tokoh-tokohnya.

"Stereotype" diartikan sebagai "a relatively rigid and simplified or biased perception or conception of an aspect of reality, especially of persons or social groups" (Strobe, 1989: 5).Stereotype muncul dalam masyarakat karenanya banyaknya pengeneralisasian akan suatu hal oleh masyarakat. Pengetahuan dan pengeneralisasian ini tidak lepas dari wacana apa yang ada di lingkungan masyarakat yang membangun stereotype tersebut.

Penelitian ini menggunakan data dari 15 tokoh anime dari 13 judul anime di Jepang.Keempat belas tokoh ini memiliki penampakan fisik bertubuh gemuk (fat character), yang mana bentuk tubuh semacam ini bukanlah bentuk tubuh ideal bagi masyarakat Jepang. Dari hasil pengumpulan dan pengolahan data, didapatkan hasil mengenai stereotype yang ada dari tokoh dengan fisik gemuk. Hanya dua orang tokoh dari lima belas tokoh yang merupakan peran utama dalam animeanime tersebut. Kedua tokoh utama ini, Haruyuki Akita (Accel World) dan Gouda Takeo (Ore no Monogatari) memiliki karakter yang berbeda, walaupun sesama tokoh utama. Tokoh Haruyuki Akita digambarkan sebagai sosok anak laki-laki yang penakut, pengecut, pemalu dan tidak 
memiliki kepercayaan diri. Karakter tokoh Gouda Takeo digambarkan berkebalikan dari tokoh Haruyuki Akita. Gouda Takeo merupakan tokoh yang suka membantu orang lain, tidak pendendam, rela berkorban dan penolong. Sedikitnya jumlah fat character yang menjadi tokoh utama dalam anime berkaitan dengan stereotype bentuk tubuh dalam anime dan manga di Jepang. Brenner menyebutkan bahwa kebanyakan karakter dari tokoh ditentukan dari bentuk tubuhnya, tidak banyak yang melenceng dari stereotype akan bentuk tubuh tokoh dengan karakter yang dibawanya. Pada anime dan manga untuk laki-laki, tokoh hero umumnya digambarkan sebagai pemuda kurus/ langsing atau laki-laki berotot yang pandai bela diri. Untuk tokoh heroine, digambarkan sebagai perempuan dengan tubuh langsing dan mungil atau perempuan dewasa dengan tubuh langsing seperti jam pasir (2007: 44-46). Gambaran tokoh semacam ini jelas bertolak belakang dengan penampilan fisik yang dimiliki oleh fat character. Pembentukan visual tokoh utama sebagai sosok yang tampan, cantik dan langsing ini disesuaikan dengan harapan para penikmat karya tersebut. Tokoh utama dengan penampilan menarik, sesuai dengan bayangan ideal pembaca/ penontonnya, tentu akan menaikkan rating dan popularitas dari karya itu sendiri.

Selain dua tokoh fat character sebagai tokoh utama, dua belas tokoh lainnya bertindak sebagai tokoh tambahan dan memiliki karakter yang beragam. Hanya ada 6 tokoh dalam anime-anime tersebut yang memiliki karakter positif.12 orang tokoh, termasuk 3 tokoh dari karakter positif, memiliki karakter negatif. Secara garis besar, karakter yang dimunculkan pada fat character di anime-anime ini adalah rakus (gemar makan), ceroboh, penakut, pemalu/ tidak percaya diri, dan otaku.Kelima stereotype ini mengarah pada stereotype negatif, sekalipun terdapat pula stereotype positif dari fat character yang muncul di anime-anime tersebut seperti setia kawan, rela berkorban, dan rela berkorban. Namun, stereotype negatif yang terdapat pada fat character lebih ditonjolkan daripada stereotype positifnya, sehingga imej akan stereotype dari fat character yang muncul di anime cenderung negatif, dan seolah menunjukkan karakter dari tokoh di luar fat character lebih baik daripada tokoh fat characer itu sendiri. Sebagai mana yang telah disebutkan sebelumnya, stereotype fat character yang negatif ini semakin memantapkan pandangan yang ada di masyarakat bahwa langsing identik dengan sehat, dan gemuk adalah sebaliknya; gemuk sama dengan jelek, langsing sama dengan cantik/ tampan; langsing adalah normal dan gemuk adalah abnormal.

\section{SIMPULAN}

Hasil penelitian menunjukkan bahwa dengan proses normalisasi berupa pemeriksaan kesehatan tahunan pemerintah Jepang telah berhasil mengubah pola pikir dan cara berperilaku penduduk Jepang untuk hidup lebih sehat dengan bertubuh langsing.Meskipun wacana mengenai gemuk/ langsing itu sendiri sudah ada sebelum adanya wacana Metabo Law, namun dengan adanya Metabo Law semakin memperkuat dan menormalkan pandangan masyarakat bahwa langsing identik dengan sehat, dan gemuk adalah sebaliknya; gemuk sama dengan jelek, langsing sama dengan cantik/ tampan; langsing adalah normal dan gemuk adalah abnormal.

Wacana Metabo Law yang dibangun oleh pemerintah mengenai gemuk/ langsing baik sebagai suatu kenormalan maupun sebagai upaya penyadaran menyebar ke bidang-bidang lainnya dan salah satu reproduksinya menyasar pada industri hiburan anime. Reproduksi wacana Metabo Law dalam anime terlihat pada terbentuknya karakter tokoh-tokoh yang didominasi dengan tokoh langsing, tampan dan cantik dan membentuk sebuah 
stereotype akan tokoh gemuk atau fat character. Dari 14 fat character di 13 judul anime, didapatkan adanya lima stereotype fat character, yaitu stereotype rakus (gemar makan), ceroboh, penakut, pemalu/ tidak percaya diri, dan otaku. Kelima stereotype ini mengarah pada stereotype negatif, sekalipun terdapat pula stereotype positif dari fat character yang muncul di animeanime tersebut. Akan tetapi, wacana yang ditonjolkan dalam anime adalah stereotype negatif dari fat character. Hal ini terlihat pula dengan jarangnya fat character menjadi tokoh utama dalam anime. Stereotype negatif yang dimunculkan pada fat character akan turut membentuk body image negatif terhadap orang-orang bertubuh gemuk, sehingga dengan demikian wacana yang dibangun melalui Metabo Law akan terus berkembang dan melekat pada masyarakat Jepang, di semua lapisan masyarakatnya.

\section{DAFTAR PUSTAKA}

Brenner, Robin E. 2007. Understanding Manga and Anime. Connecticut: Libraries Unlimited.

Eriyanto. 2003. Analisis Wacana. Yogyakarta: LKiS.

Foucault, Michel. 1977. Discipline and Punish: The Birth of the Prison. Trans. Alan Sheridan. England: Penguin Groups.

Foucault, Michel. 2002. Power/ Knowledge. Wacana Kuasa/ Pengetahuan. Penj. Yudi Santosa. Yogyakarta: Bentang Budaya.

Nazilaturrahmah, Sally. 2016. Sistem Rawat Asuh Lansia Di Jepang Yang Tercermin Dalam Drama Tsui No Sumika Karya Sutradara Fuji Yuya.Malang: FIB UB. Skripsi tidak diterbitkan.
Udasmoro, Wening. 2009. Pengantar Gender dalam Sastra. Yogyakarta: FIB UGM.

Strobe, Wolfgang, ed. 1989.Stereotype and Prejudice: Changing Conception. New York: Springer Science+Bussiness Media, LLC.

\section{Daftar Laman}

Bray, George A. 2011. A Guide To Obesity And The Metabolic Syndrome : Origins And Treatment. BookZZ.org Mudhoffir, Abdil Mughis. 2013. Teori Kekuasaan Michel Faocault: Tantangan bagi Sosiologi Politik. Diakses pada tanggal 3 Maret 2018 dari

http://journal.ui.ac.id/index.php/mjs/ article/view/3734/2973

Jayarajan, Nandini. 2011. The Fat's on Fire: Curbing Obesity in Japan. Diakses pada tanggal 3 Maret 2017, dari

http://www.bu.edu/themovement/201 1/05/29/the-fats-on-fire/

Manansala, Mark J. 2013. Japan and the "Metabo Law. Diakses pada tanggal 3 Maret 2017, dari https://www.slideshare.net/markppt/ Norimitsu, Onishi. 2008. Japan, Seeking Trim Waists, Measures Millions. Dari www. The New York Times.

Nakamura, David. 2009. Fat in Japan?You're breaking the Law. Global Post. Pri.org.

Oda, Barron T. 2010. An Alternative Perspective to Battling The Bulge: TheSocial and Legal Fallout of Japan's AntiObesity.Legislation.Asian-Pacific Law \& Policy Journal Vol. 12:1 (Hal: 249-330).

Rini, Sandra. 2015. Sindrom Metabolik. J Majority.Volume 4 Nomor 4.Februari 2015. 
Sassi, Franco. 2010. Obesity and the Economics of Prevention: Fit Not Fat. OECD (Organization for Economic Co-operation and Development). BookZ.org. Pdf.

Accel World. Diakses dari https://www.kurogaze.top/anime/acc el-world-batch/

Dragon Ball. Diakses dari https://www.kurogaze.top/anime/dra gon-ball-super/

Full Metal Alchemist. Diakses dari http://www.soulreaperzone.com/full metal-alchemist-brotherhood/

Gin no Saji. Diakses dari http://www.soulreaperzone.com/silve r-spoon-season-1-bluray-480p-50mb720p-90mb-mkv/

Gintama. Diakses dari http://www.soulreaperzone.com/gint ama-season-01-to-04-episodes-720p60mb-mkv/

High School of the Dead. Diakses dari http://www.soulreaperzone.com/high school-of-the-dead-uncensored-bluray480p-70mb-720p-110mb-mkv/

Hunter $x$ Hunter. Diakses dari http://www.soulreaperzone.com/hunt er-X-hunter-2011/

Kuragehime. Diakses dari http://www.soulreaperzone.com/dow nload-princess-jellyfish-bluray-minimkv/

Naruto. Diakses dari https://www.kurogaze.top/anime/nar uto-shippuden/

One Piece. Diakses dari https://www.kurogaze.top/anime/one -piece/

Ore Monogatari. Diakses dari http://www.soulreaperzone.com/oremonogatari-episodes-download480p-60mb-720p-90mb-mkv/

Stein;s Gate. Diakses dari http://www.soulreaperzone.com/stein s-gate-episodes-bluray-bd-480p60mb-720p-100mb-mkv/ 